\title{
Pure Versus Hybrid Competitive Strategy: Evidence from Tunisian Manufacturing Industries
}

\author{
Asma Zgarni ${ }^{1} \&$ Lamia Gharbi ${ }^{1}$ \\ ${ }^{1}$ El Manar University, FSEG, Tunis \\ Correspondence: Asma Zgarni. E-mail: asmazg12@yahoo.fr
}

Received: July 17, 2019

Accepted: September 3, 2019

Online Published: June 30, 2021

doi:10.5539/ass.v17n7p1

URL: https://doi.org/10.5539/ass.v17n7p1

\begin{abstract}
This article proposes to decide on the impact of external and internal factors (competitive forces and strategic capabilities) on strategic competitive choices (pure or hybrid). Using a sample of Tunisian companies operating in the manufacturing industry, the results show that face to the competition' intensity, companies opt for competitive hybrid strategies at the expense of pure ones only when they have strong combined strategic capabilities. However, when they have a stock of capabilities less rich and less diversified, they have interest to pursue a pure competitive strategy. Moreover, the study shows that the pure competitive strategy differs according to the nature of the strategic capabilities held.
\end{abstract}

Keywords: competitive intensity, strategic capabilities, pure competitive strategy, hybrid competitive strategy, cost domination, differentiation, concentration

\section{Introduction}

This research focuses on the competitive strategies (cost, differentiation, concentration) proposed by Porter (1980) in the face of competitive intensity, whose competitive advantage can only be assured when they are mutually exclusive and whose the combination risks leading the company to become bogged down in a non-performing middle path. If multiple works, which succeeded him, supported it (Hall, 1981; Hambrick, 1983; Galbraith \& Schendel, 1983; Dess \& Davis, 1984; Parker \& Helms, 1992; Nayyar et al., 1994), many other more recent works have upset him and argue in favor of the combination of higher-performing strategies (Allen \& Helms, 2006; Miller, 1992; Acquah et al., 2008; Jonhson \& Scholes, 2008; Hassen et al., 2015, Gaberiellson et al., 2015). This new trend states that in order to protect oneself against the new competitive reality, and to obtain a competitive advantage that is difficult to imitate and sustain, companies must master the "cost-quality" couple (Billard, 1991).

The explanatory factors for these competitive strategies have given rise to several empirical studies that remain controversial (Murray, 1988; Spanos \& Lioukas, 2001; Spanos et al., 2004; Parnel, 2011; Batista et al., 2016). Indeed, if competitive strategies originate in the structure of the industry and more specifically in the competitive intensity of the sector as advocated by Porter (1980) and his supporters, the resource approach (Wernerfelt, 1984; Barney, 1991) has contradicted these remarks to put these competitive strategies back to the nature and availability of the resources and strategic capabilities that the company has. More recent work has just shown the complementarity of these two approaches in explaining these strategies (Spanos \& Lioukas, 2001).

The objective of this research is therefore to decide on the priority of pure competitive strategies as opposed to hybrid strategies on the one hand, and on the possible complementarity of competitive intensity and strategic capabilities in the explanation of competitive strategies in the world of Tunisian manufacturing industry. So we can thus ask the following research question:

Face to increased competition'intensity, the nature and the availability of their strategic capabilities, should companies pursue pure or hybrid competitive strategies?

In order to provide some answers to this question, we structure this article in six sections. The first will present the theoretical foundations of the study (competitive forces approach and RBV). The second will be devoted to the development of hypotheses and the conceptual model of research. The third will outline the research methodology. The fourth will be reserved for the results of the survey. The fifth will present the discussions of the results. Finally, the last section will focus on managerial implications. 


\section{Theoretical Framework}

\subsection{The Determinants of Strategic Choices}

Although the analysis of the external environment in general, was evoked by the first model of strategic analysis (SWOT), it was necessary to wait the works of Porter $(1980,1985)$ to explicitly integrate the role of sectoral aspects in the competitive process, notably through the famous analysis of competitive forces.

\subsubsection{Competitive Forces Approach}

Two main approaches characterize competition research: the structural and the behavioral approach (Le Roy, 2004). As for the structuralist approach, it postulates that the intensity of competition depends on the structural factors and not on the conscious actions of firms as in the context of the behavioral approach (Le Roy, 2004). Besides, the sole purpose of the companies is to adapt to the demands of the environment in terms of demand and technologies. On this matter, Le Roy (2001) states that his extensions in management sciences can be divided into two approaches. The first, defended by Porter (1982), is direct. However, the second can be described as indirect since it considers environmental adaptation as the driving force of the decision (Ansoff and McDonnell, 1990).

We focus our interest exclusively on Porter's approach, which is part of this structuralist (direct) approach to industrial economics (SCP). This approach breaks with a narrow view of competitive relationships based exclusively on relative market share with strategic analysis tools (matrices) while offering an expanded analysis of competition. Porter (1980) assumes that the origin of the competitive advantage lies in the environment. He proposed an attractive model of sector analysis, much richer than that of the SCP model, in order to guide managers in their strategy formulation process. This author introduced the notion of "force" to better explain structural factors. According to this author $(1980$, p. 3), "the structure of a sector has a strong influence on the determination of the competitive game's rules and on the strategies to which the firm is able to resort". Five structural forces, which determine the competitive intensity in a sector of activity, have been defined, namely: existing competitors, new entrants, substitute products, bargaining power of customes and bargaining power of suppliers.

This approach is qualified as the competitive forces approach according to the terminology of Teece et al. (1997) provides a comprehensive framework for strategic analysis (Galbreath and Galvin, 2008). Indeed, in addition to analytical techniques aimed at analyzing the industry and its evolution, it makes it possible to identify the competition and the positioning of companies in the face of this competition. This offers the opportunity to define the right competitive strategy that can only strengthen the company's position in the market. However, since it focuses exclusively on external factors in the definition of strategic choices, this approach has just been questioned, since in the same sector, different levels of performance have been recorded thanks to the strategy pursued. This gave rise to a second strategic analysis approach, namely the Resource Based View.

\subsubsection{The Resource Based View}

The essential reference of this approach remains to Penrose (1959) who considers the company as a collection of physical and human resources who are deployed by the managers. Their combination allows each company to create unique, subjective and specific productive opportunities for growth. Indeed, according to this author, this "inner world" has a capacity similar to that attributed to the external forces such as competitive pressure or customer requirements.

Thereafter, we note the works of the Harvard School that stipulates that strategic choices are based not only on the study of environmental opportunities and threats, but also on evaluating the strengths and weaknesses of the company. The latter leads to the identification of the distinctive competences of the company. However, it is important to note that the resource approach did not know a real institutionalization that from the proposals of Wernerfelt (1984) who first used the term Resource Based View (RBV), which, while taking inspiration from the SWOT model, refers resources to the strengths and the weaknesses of a company. However, it was only with Barney (1991) that resources were seen as the sources of sustainability and the substitutability of competitive advantage. Indeed, for this author the resources were defined as: "all assets, capabilities, organizational processes, attributes of the company, information, knowledge, etc. controlled by a company that allows it to design and implement strategies which improve its efficiency". Through this rather rich and complete definition, the capabilities of the company can be considered as resources.

The resource approach is, therefore, a true renewal in the study of strategy, where the company is considered as a set of unique resources that can guide its future trajectory, strategy, competitive advantage and rents (Barney, 1991). Compared to the neoclassical approach, which considers that resources are mobile and homogeneous, the 
resource approach considers that companies are heterogeneous due to the resources that they disposed, and that resources are not perfectly mobile between companies (Barney, 1991). According to Barney (1991), the choice between Porter's two generic strategies (1980) depends on the presence or absence of certain resources. Fernandez and Le Roy (2010) ensure that the theory RBV encourages the company to pursue individual strategy.

Although, pioneering research on resources shows an ambiguity between the terms "resources" and "capabilities". It was not until Amit and Schoemaker (1993) who defined the resources "as the assets owned and controlled by the firm", whereas the capabilities were recognized as the capacity of exploitation and combination of the resources by means of the organizational routines in the goal of continuing its path. The complex interactions linking resources create specific information processes that are both tangible and intangible and that build capabilities.

Nevertheless, when these capabilities constitute the driving force for the sustainability of the co-competitive advantage created (cost / differentiation), of the increase of the efficiency of the production, the shortening of the delays of the deliveries and the increase of the competitiveness, they reveal a strategic character [Day (1994), Spanos and Lioukas (2001), Desarboo et al. (2005)]. Among the different types of existing strategic capabilities, we choose in this article, those most cited in the literature, in particular: managerial, technological, marketing, market linking and information technology.

\subsubsection{Complementarity of the Porter's Approach and the RBV:}

Despite their divergence in the explanation of the origin of the strategy and the competitive advantage, these two approaches are complementary in that they also show certain similarities (Amit \& Shomaker, 1993, Peteraf, 1993). Indeed, according to Spanos and Lioukas (2001), these two approaches agree on the possibility for the company to record returns that exceed the average, which gives it the opportunity to acquire a favorable strategic position (Conner, 1991). If external factors justify the strategy defined by Porter's approach, purely internal factors are considered the driving force of this strategy according to the RBV. In this sense, some authors (Wernerfelt, 1984) go so far as to say that these two approaches are only the two sides of the same coin. In the same sense, Barney and Griffin (1992) state that the logic of value creation implies that this last part of the internal capacities towards the pursued strategy and also of this strategy towards the competitive environment (Spanos \& Lioukas, 2001). From a similar perspective, Barney, Spender, and Reve (1994) argue that in order to implement business strategy, the required skills and the competitive environment needed to be examined concomitantly (Penrose, 1959; Amit \& Schoemaker, 1993). These authors join the pioneering SWOT strategic analysis model that summarizes the company's resources in its strengths and weaknesses and the competitive environment in opportunities and threats (Spanos \& Lioukas, 2001).

The comparison of these two approaches and their integration in a composite framework finds justifications in the following points (Spanos \& Lioukas, 2001):

-complementarity in the explanation of the source of competitive advantage and performance (internal with external determinants)

-the intersection of studied phenomena namely sustainable competitive advantage and strategic choices.

\subsection{Competitive Strategic Choices: Pure and Hybrid}

Popularized by Porter (1982), the term "competitive strategy" has been widely studied in the strategic literature, especially the work of Dess and Davis, (1984); Miller (1988) (Duquesnois et al., 2009). In 1980, Porter proposed a typology of generic strategies (business strategies) based on two dimensions: competitive advantage and the field of competition. It's about the cost leadership, the differentiation and the focus. Porter (1980) confirms that an enterprise must choose only one of these strategies to gain a strong competitive position and avoid getting bogged down in a middle path translating necessarily by the lasting reduction of benefit (Hambrick, 1983; Dess \& Davis, 1984; Porter, 1980, 1985).

However, Porter's model has been widely criticized, essentially for the exclusivity of strategic choices. A second stream of research better adapted to the current changing context defends rather the dynamic dimension of strategy and competitive advantage (Billard, 1991). In this regard, Hambrick (1983) argues that any generic strategy is a composite of many variants that are not all equally relevant to a given situation. This current is opposed to Porter and supports the idea that competitive strategies might rather be combined (Murray, 1988; Miller, 1992; Allen \& Hlems, 2006; Hansen et al., 2015; Gaberiellson et al., 2015).

According to Billard (1991) and Miller (1992), the real causes of a bad or even dangerous situation in the company are rather the ambiguity, the uncertainty, the chance or the trial and error as for the choice of the strategy. Monitoring more than one strategy does not necessarily lead to failure as long as the company has the 
capabilities and abilities to implement them while moving away from the middle path (Jaoua A., 2005) or the "stuck in the middle" strategy where a company fails to combine cost and differentiation strategies. Indeed, according to Miller (1992), the most successful strategies i.e. the most difficult to imitate are those that use a range of organizational skills at the same time: marketing, production, design, distribution, and procurement, indeed a "complex orchestrated recipe".

\subsection{Development of the Model and Hypotheses}

With reference to Porter's approach and RBV, our conceptual composite model proposes that the competition's intensity explains differently the different business strategic choices, that are also mobilized differently by the nature and sufficiency of the strategic capabilities available to the company (Figure 1).

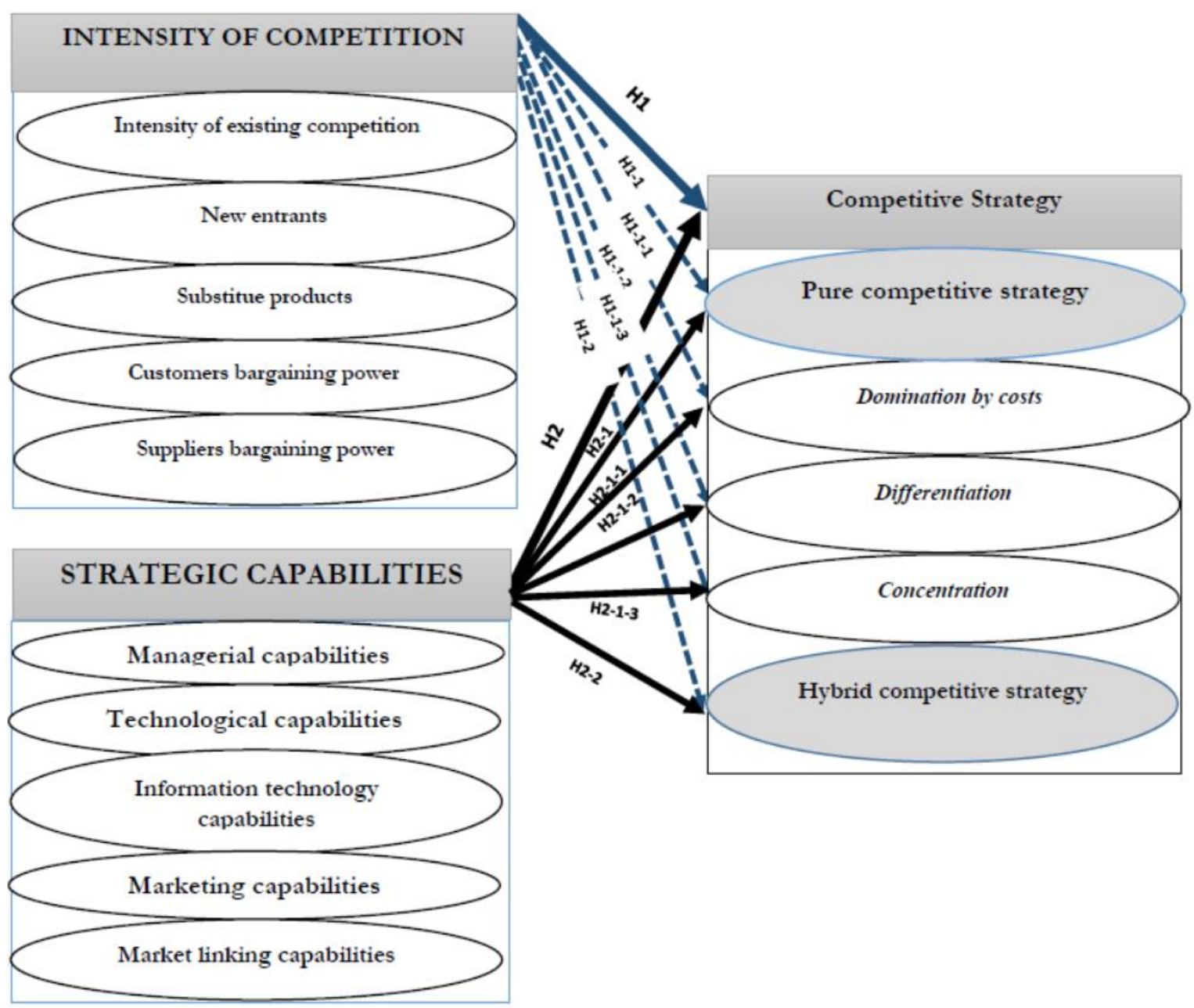

Figure 1. Conceptual Model of Research

\subsection{The Impact of Competitive Intensity on Pure and Hybrid Competitive Strategies}

The question of external factors that lead to pure competitive strategies or hybrid one, has been strongly debated by many authors. The problem is to know which competitive strategy is best adapted to the environment's changes in general and competitive intensity in particular. In an American rail context, Smith and Grimm (1987) have shown that, in order to preserve their competitiveness in an environment of high competition, the niche strategy seems the most adopted. However, faced to the existing rivalry, Enz (2010) shows that companies are moving towards differentiating their products. Crook et al. (2003) empirically prove that differentiation is the favorable strategic route to successfully dealing with clients' bargaining power due to their size, concentration and purchasing volume. In this sense, Harrison (2003) shows empirically that companies are actively opting for differentiation in order to retain their customers and block attempts to bring in new entrants. In contrast, Hambrick (1983) and Miller (1988) argue, respectively, that the cost leadership is not the right alternative in an environment marked by dynamism, especially for high-performance companies.

Nevertheless, D'Aveni (1995) argues that in a context of hypercompetition, the competitive advantage can no 
longer be sustainable but rather a series of temporary and therefore non-exclusive benefits under the fear of rapid imitation. In the same perspective, Duquesnois et al. (2010) show, through an empirical study, that companies operating in a context of crisis marked by strong competitive pressures tend to pursue hybrid strategies, combining mainly differentiation and niche strategies. In the same vein, Murray (1988) argues that exogenous prerequisites for the cost dominance strategy (structural features of the industry) and product differentiation strategies (consumer characteristics and preferences) are not mutually exclusive. Similarly, Billard (1991) argues that in order to protect against the competition, which has become more intense than ever before and to obtain a competitive advantage that is difficult to imitate, companies must master the couple "cost-quality" which is not considered as a benefit but rather as an absence of a competitive handicap. From them, Kotha and Vadlamanni (1995) explain that to succeed in a fairly complex business environment in the 21st century, hybrid strategies correspond exactly to what is needed. Gabrielsson et al. (2015) reveal, also, that the competition's intensification in high-tech markets is pushing firms to pursue hybrid strategies. In this context, Ortega et al. (2009) show that currently a large number of organizations tend to use different types of hybrid strategies because they are associated with higher levels of performance than those pure competitive strategies.

Following the above developments, we make the following central hypothesis:

Hypothesis 1: The competition' intensity favors competitive strategies

From this hypothesis, follow the following sub-hypotheses:

Hypothesis 1-1: The competition's intensity favors pure competitive strategic choices

Hypothesis 1-1-1: The competition's intensity favors cost dominance

Hypothesis 1-1-2: The competition's intensity favors differentiation

Hypothesis 1-1-3: The competition's intensity favors concentration

Hypothesis 1-2: The competition's intensity favors hybrid competitive strategies

\subsection{The Impact of Strategic Capabilities on Strategic Choices}

On this topic, Spanos and Likouas (2001) have established empirically that the availability of specific resource stocks (managerial, marketing and technical capabilities) is decisive to develop competitive strategy and achieve a competitive advantage. In a deeper perspective, Parnell (2011) shows that the competitive strategies pursued differ according to the strategic capabilities held.

From previous developments, we propose the hypothesis below:

Hypothesis 2: Insufficient strategic capabilities favors adoption of competitive strategies

From this hypothesis, can emerge the first sub-hypotheses:

Hypothesis 2-1: The nature of strategic capabilities held determines the nature of pure competitive strategies

Regarding the holding of managerial strategic capabilities, and following an empirical study conducted with 211 Brazilian companies in the textile sector, Batista et al. (2016) have just shown the weight of these managerial capacities in the choice of a pure competitive strategy of domination by the costs. This same result was also proved empirically by the work of Parnell (2011). This author manages to show that managerial capacities, particularly in terms of cost control and efficiency of production, have the effect of favoring the continuation of this strategy.

As for the impact of technological capabilities on the nature of the pure competitive strategy chosen, Chandler and Hanks (1994) empirically prove in the context of northwestern Pennsylvania that the use of differentiation through innovation and quality is positively related to quality and innovation resources and capabilities. In the same perspective, Ortega (2010) demonstrates, in a Spanish context, that the adoption of differentiation is dependent on the stock of technological capabilities arranged by the firm. However, on a sample of Brazilian companies in the textile sector, Batista et al. (2016) deny the impact of technological capabilities on differentiation.

Concerning the strategic capabilities of information technology that show a positive impact on pure competitive strategies, Miles and Snow (1978) noted that prospectors need the most complex coordination and communication mechanisms since they are the more related to the development of new products to support their competitiveness. In this regard, Desarboo et al. (2005), empirically prove that "prospectors" that are differentiating and innovative in nature have high capabilities in information technology.

As for marketing capabilities, and in a Brazilian industrial context, Batista et al. (2016) show that the latter push 
companies to opt for focus strategies. Indeed, since consumers in the clothing industry are very disparate and vary massively according to their age, sex or income level, very many segments can be identified, thus favoring the pursuit of differentiation focus. In this same perspective, Parnell (2011), through a sample of companies from Argentina, Peru and the United States, shows that marketing capabilities favor the recourse to concentration and more precisely the focus of efforts on a given segment.

Finally, previous empirical studies confirm the positive effect of market-link capacities on the choice of a concentration strategy. As such, Weerawardena (2003) confirms the role of market-based learning capacity in competitive strategy. Desarboo et al. (2005) empirically prove that firms with market link capabilities are essentially "defensive" firms. This result was also confirmed by Parnell (2011), Collis and Montgomery (2008) and Jusoh and Parnell (2008).

Thus, from these developments, we can formulate the following sub-hypotheses:

Hypothesis 2-1-1: managerial Capabilities favor domination costs

Hypothesis 2-1-2: Technological Capabilities favor Differentiation

Hypothesis 2-1-3: Information Technology Capabilities favor Differentiation

Hypothesis 2-1-4: Marketing Capabilities favor Concentration

Hypothesis 2-1-5: Market Linking Capabilities favor Concentration

According to Miller (1992), the most successful strategies, i.e. the most difficult to imitate are those that use a range of organizational skills at the same time: marketing, production, design, distribution, and procurement. With reference to Gaberiellson et al. (2015), the possession of key strategic resources is necessary for the pursuit of the most complex strategy namely the hybrid one (Spanos \& Lioukas, 2001). The higher the strategic nature of these key resources (RBV), the more firms tend towards hybrid strategies. Parnel (2011) finds that the strategy of combining cost leadership and differentiation has been pursued by companies with strong managerial and technological strategic capabilities.

Thus, from these developments, we propose the following second sub-hypothesis:

Hypothesis 2-2: combined strategic capabilities favor hybrid competitive strategies

\section{Research Methodology}

\subsection{Measurement of Variables}

Using the scale of Al-Rfou (2012), we measured the dimension intensity of existing competition. For other competitive forces we adopt the measurement scales of Mia and Clarke (1999) adopted by Weerawardena (2006). The scales of Desarbo et al. (2005) was be used for measuring all strategic capabilities.

The cost-dominating was measured using the competitive dimensions of Dess and Davis (1984) such as adapted by Le Roy $(2001,2003)$. For the differentiation ${ }^{1}$ and the concentration, we opt for the scales of Zahra and Covin (1993) as adapted by Parnel (2011). For the hybrid strategy, we used all the items corresponding to the three competitive strategies proposed above 20 items are used to measure this variable. Like Ortega et al. (2007), companies checking items that belong to more than one strategy, with a value above average, are considered adopting hybrid strategy. Asked persons must express their degree of agreement or disagreement for each item of the different scales of measurement proposed for each of the variables selected for the study, using a Likert scale consisting of 7 response choices, where 1 and 7 correspond, respectively, to the response "very low" and "very high".

\subsection{Sampling, Administration and Data Collection}

In terms of sampling, we opted for the the reasoned choice sampling method. The mother population brings together Tunisian manufacturing industrial enterprises, in particular in the textile and clothing sector, electrical, electronic and household appliances, chemical and agro-food products, any size and activity regime confounded. As for the questionnaire, we had checking the validity of content (consensual ${ }^{2}$ and facial ${ }^{3}$ ). Subsequently, we administered it ${ }^{4}$, in its final version, to the directors (CEOs) of the companies. We are distributing 400 questionnaires, but we only collected 236 or $59 \%$ whose only 203 were exploitable with an $85.5 \%$ rate.

\footnotetext{
1 single global dimension has retained

2 appreciation of peers and experts

3 pre-test with 12 companies

4 face-to-face mode
} 


\section{Results}

Before proceeding to the hypothesis tests, we made sure in a first time of the reliability and the dimensionality of the different scales chosen 5 . Subsequently, the use of the structural equations method, revealing a good quality of fit of the global model, allowed us to empirically validate the research hypotheses and obtain the following results (Appendix A.1.). The relationship between the competition's intensity and competitive strategies is positive and significant, confirming $\mathrm{H} 1$ and $\mathrm{H} 2$. More specifically, the effects of competitive intensity on cost dominance, on differentiation, on concentration and on hybrid strategy are, respectively, positive and significant, hence the confirmation of the H1-1-1, H1-1-2 H1-1-3 and H1-2.

Concerning the second explanatory variable of our model, the results allowed us to affirm the positive and significant impact of certain strategic capabilities on the different pure competitive strategies. More specifically, managerial abilities positively affect the costs domination, thus confirming H2-1-1. As for technological and information technologies capabilities, they reveal a positive and significant effects on differentiation. This allows us to confirm H2-1-2 and H2-1-3. Finally, surprisingly, the null impact of marketing and market-linking capabilities on focus has led us to exile H2-1-4 and H1-2-5.

Furthermore, the combining strategic capabilities has positive and significant effect on hybrid competitive strategies, so we confirm H2-2.

\section{Discussions}

The global model test confirmed that in front of the competition's intensity, the first strategy adopted in our sample is that of concentration, then the costs leadership, then hybrid strategy and finally the differentiation. The first result, which converges with Smith and Grimm (1987) but differs from Miller (1988), suggests that the insufficiency of the resources which is supposed to allow these companies to operate on a wider field of competition, forces them to focus on particular niches in order to be able to satisfied the chosen customer target. The second result, which resembles that of Tan and Litschert (1994) but diverges from Miller (1988), suggests that faced with the new competitive reality, some enterprises are moving towards markets where customers is very price sensitive. As for hybrid strategies, it turns out that in the highly competitive context of Tunisian companies, where competitors are no longer just national, but also international and where competitive advantage can no longer be sustainable as before, the latter seem aware of the compelling need for combining these two types of advantage (cost / differentiation) in order to cope with the shortening of product life cycles and the risk of imitation fast. This result goes hand in hand with the ideas of D'Aveni (1995). Finally, the last result, which corroborates Ward and Duray (2000) but does not join Tavitiyaman et al. (2011), shows that some firms, that are exposed to international competition (export market, foreign companies established in Tunisia), are obliged to differentiate their offer by different modalities, such as quality, product innovation, processes, or marketing, to satisfy the clientele which is open to a wide range of products.

In total, in our sample and in accordance with Porter (1980) and Desarboo et al. (2005), the intensity of competition seems to favor pure competitive strategic choices, including cost-dominated strategies, differentiation and concentration strategies. It also strongly encourages companies to combine cost and differentiation strategies. However, these findings allow us to infer that the intensity of competition favors far more pure competitive strategies than hybrid strategies (Table 1).

Table 1. Hierarchy of strategic competitive choices based on competitive intensity

\begin{tabular}{cc}
\hline Factor & Hierarchy of strategic competitive choices \\
\hline & 1. PURES \\
Competition' intensity & 2. HYBRIDES \\
\hline
\end{tabular}

As for strategic capabilities, they seem to favor the priority use of hybrid competitive strategies. Subsequently come the pure competitive strategies of domination by the costs, and finally of differentiation. The pure strategy of concentration seems independent of strategic capabilities (Table 2).

More precisely, managerial capabilities appear to be critical to achieving efficiency and effectiveness and favor individual pursuit of a cost-dominating. We thus join Parnell (2011) and Batista et al. (2016), but we diverge from Chandler and Hanks (1994). Like Chandler and Hanks (1994) and Ortega (2010), the companies in our sample base their differentiation on strong technological capabilities which access is not easy on the market. This

5 ACP, Cronbach's Alpha, AFC 
result seems to differ from Batista et al. (2016). In addition, IT capabilities play a major role in supporting differentiation. This result joins that of Desarboo et al. (2005). However, contrary to expectations, the impacts of marketing and market linking capabilities on concentration are insignificants, suggesting that Tunisian firms adopting concentration are using other capabilities. The first result upset the ideas of the authors Batista et al. (2016) and Parnel (2011), however, the second one goes against Collis and Montgomery (2008), Jusoh and Parnell (2008) and Weerawardena (2003).

Concerning the impact of the combination of different strategic capabilities on hybrid competitive strategies, it is positive and significant. Indeed, having a rich portfolio of strategic resources allows the pursuit of hybrid strategies. This result, which is consistent with the hybrid approach, resembles that of Gaberiellson et al. (2015), Ortega et al. (2007) and Parnel (2011).

Table 2. Hierarchy of strategic competitive choices based on strategic capabilities

\begin{tabular}{cc}
\hline Factor & Hierarchy of strategic competitive choices \\
\hline \multirow{2}{*}{ Strategic Capabilities } & 1. HYBRIDES \\
& 2. PURES \\
\hline
\end{tabular}

For conclusion, we can propose the matrix below to guide managers on their choice of pure or hybrid competitive strategy (Table 3):

Table 3. matrix of competitive strategic choices

\begin{tabular}{ccl}
\hline \multicolumn{1}{c}{ Competition intensity } & Low & \multicolumn{1}{c}{ High } \\
Strategic capabilities & $\bullet$ Concentration \\
\hline Other than marketing and market linking capabilities & $\bullet$ Cost domination \\
Managerial capabilities & $\bullet$ Differentiation \\
Technological capabilities & $\bullet$ Differentiation \\
Information technological capabilities & $\bullet$ Hybrid competitive strategy \\
Combined capabilities & & \\
\hline
\end{tabular}

\section{Managerial Implications}

The results of this research are of considerable interest to managers of Tunisian companies who can serve as guidelines of diagnostic that can enlighten their path in terms of strategic choices based on different situations of competition and resources' availability. Indeed, the mangers must evaluate the availability of strategic capabilities necessary to develop competitive strategies. However, when the capabilities are not consistent with the chosen strategy, it is incumbent on them to review their choices and to modifying them. Nevertheless, the lack of relationship between marketing capabilities, market linkage capabilities and the focus strategy may be an important message to Tunisian manufacturers who do not have these capabilities, who should not consider this inadequacy as a disability to the adoption of focus strategy.

One more implication is that hybrid competitive strategies can sometimes be the appropriate solution to the intensification of competition and even preferred over the pure differentiation strategy. Nevertheless, adopting this strategy can only be possible for business managers if they have sufficient strategic capacity to support and implement them. These managers must refrain from pursuing a hybrid strategy if their strategic capabilities are not rich enough. In this case, it would be detrimental for them to opt for a pure competitive strategy of cost or differentiation depending on the stock of strategic capabilities held at the risk of becoming bogged down in an ambiguous middle path and low profitability.

The present results are also important for policy makers of which the development and success of manufacturing industries, the respect of the rules of competition and the welfare of the consumer, constitute their first concern. Indeed, the cost leadership can end up in a price war, with the intention of eliminating a competitor and monopolizing the market can adversely affect the smooth running of competition.

\section{Conclusion}

This research is a contribution to debates on the determinants of strategic competitive choices and the primacy of pure competitive strategies over hybrid ones and vice versa. Previous research has generally been divergent as to 
the primacy of external factors to the detriment of internal factors in explaining these strategic choices and vice versa. Few works have brought these two types of factors together in a composite model crowned by the definition of favorable conditions for pursuing a pure competitive strategy or a hybrid competitive strategy. Moreover, this study explains, through the stock of strategic capabilities held, why, in the same sector, some companies opt for some different pure competitive strategies and why they may succeed in pursuing hybrid competitive strategies when the competitive environment demands it.

However, some limitations of this research need to be raised. A first limit refers to the choice of the Tunisian manufacturing industry to test our conceptual model that does not allow us to generalize the results to different sectors or developing countries. An inter-industry or comparison with other developing countries may extend or narrow the scope of our results (Zgarni \& Gharbi, 2019).

In addition, the present problem can be taken up by integrating other explanatory factors of the strategic choices. In fact, it is very useful to analyze the effect of a more varied stock of resources and capabilities or of the dynamic capabilities (Teece et al., 1997) on competitive strategic choices. This can enrich our dissertation and increase the interest and validity of our results. In addition, other structural, cognitive or behavioral factors can provide valuable insights.

On the other hand, in our work, we have limited ourselves to the study of the antecedents of competitive strategic choices, but the rationale for these strategic choices is to create and maintain a competitive advantage of cost or differentiation that will lead to performance. The effect of competitive strategic choices (pure and hybrid) on performance is certainly such a deserving problem, especially as companies today operate in a hyper-competitive environment where competition is global and where resources are increasingly more rare. News researches could sail to these new horizons.

\section{References}

Allen, R. S., \& Helms, M. (2006). Linking strategic practices and organizational performance to Porter's generic $\begin{array}{lllll}\text { strategies. Business Process Management Journal, 12(4), 433-454. } & \text {. }\end{array}$ https://doi.org/10.1108/14637150610678069

Amit, R., \& Schoemaker, P. J. (1993). Strategic assets and organizational rent. Strategic Management Journal, 14, 33-46. https://doi.org/10.1002/smj.4250140105

Ansoff, H. I., \& McDonnell, E. J. (1990). Implanting strategic management. Cambridge: Prentice Hall. Retirieved from https://trove.nla.gov.au/work/8830278

Barney, J. B. (1991). Firm Resources and Sustained Competitive Advantage. Journal of Management, 17(1), 99-120. https://doi.org/10.1177/014920639101700108

Barney, J., \& Griffin, R. (1992). The Management of Organizations: Strategy, Structure, and Behavior. Houghton Mifflin: Boston, MA.

Barney, Spender and Reve. (1994). Does Management Matter?: On Competencies and Competitive Advantage. Lund University Press.

Batista, P. C. de S., Lisboa, J. V. de O., Augusto, M. G., \& Almeida, F. E. B. De. (2016). Effectiveness of business strategies in Brazilian textile industry. Revista de Administração [RAUSP], 51(2), 225-239. https://doi.org/10.5700/rausp1236

Billard, L. (1991). une approche dynamique des stratégies génériques de M. Porter.

Chandler, G., \& Hanks, S. (1994). Market Attractiveness, Resource-Based Capabilities, Venture Strategies, and $\begin{array}{lllll}\text { Venture Performance. Journal of Business Venturing, 9, 331-349. } & \text {. }\end{array}$ https://doi.org/10.1016/0883-9026(94)90011-6

Collis, D. J., \& Montgomery, C. A. (2008). Competing on resources. Harvard Business Review, (July-August), 140-150.

Conner, K. R. (1991). Ahistorical comparaison of resource-based theory and five schools of thought within industrial organization economics: Do we have a new theory of the firm? Journal of Management, 17(1), 121-154. https://doi.org/10.1177/014920639101700109

Crook, T. R., Ketchen, D. J., \& Snow, C. C. (2003). Competitive edge: A strategic management model. Cornell Hotel and Restaurant Administration Quarterly, 44(3), 44-53. https://doi.org/10.1177/001088040304400305

D’Aveni, R. (1995). Hypercompétition. Vuibert, Paris. 
Day, G. S. (1994). The Capabilities of Market-Driven Organizations Reviewed work(s). Journal of Marketing, 58(4), 37-52. https://doi.org/10.1177/002224299405800404

Desarbo, W. S., Di Benedetto, C. A., Song, M., \& Sinha, I. (2005). Revisiting the Miles and Snow strategic framework: uncovering interrelationships between strategic types, capabilities, environmental uncertainty, and firm performance. Strategic Management Journal, 26, 47-74. https://doi.org/10.1002/smj.431

Dess, G. C., \& Davis, P. S. (1984). Porter's generic strategies as determinant of strategic group. Academy of management Journal, 27(3), 467-488. https://doi.org/10.5465/256040

Duquesnois, F., Le Roy, F., \& Gurau, C. (2009). Stratégies concurrentielles dans un contexte de crise: le cas de l'industrie vitivinicole. 18ème Conférence de l'AIMS, Grenoble.

Duquesnois, F., Le Roy, F., \& Gurau, C. (2010). Stratégies concurrentielles dans une industrie en crise. Le cas de l'industrie vitivinicole en Languedoc-Roussillon. Revue française de gestion, 4(n203), 41-56. https://doi.org/10.3166/RFG.203.41-56

Enz, C. A. (2010). Competitive dynamics and creating sustainable advantage. Retrieved from Cornell University, School of Hospitality Administration site: http://scholarship.sha.cornell.edu/articles/349

Fernandez, A.-S., \& Le Roy, F. (2010). Pourquoi Coopérer Avec Un Concurrent ? Une approche par la RBV, Lavoisier. Revue française de gestion, 5(204), 155-169. https://doi.org/10.3166/RFG.204.155-169

Gabrielsson, M. (2015). Realizing a hybrid competitive strategy and achieving superior financial performance while internationalizing in the high-technology. Industrial Marketing Management. https://doi.org/10.1016/j.indmarman.2015.07.001

Galbraith, C., \& Schendel, D. (1983). An empirical analysis of strategy types. Strategic Management Journal, 4(2), 153-173. https://doi.org/10.1002/smj.4250040206

Galbreath, J., \& Galvin, P. (2008). Firm factors, industry structure and performance variation: New empirical evidence to a classic debate. Journal of Business Research, 61, 109-117. https://doi.org/10.1016/j.jbusres.2007.06.009

Hall, W. K. (1981). Survivre dans un environnement plus rude. Harvard L'Expansion, 56-68.

Hambrick, D. C. (1983). Some Tests of the Effectiveness and Functional Attributes of Miles and Snow's Strategic Types. Academy of Management Journal, 26(1) 5-26. https://doi.org/10.2307/256132

Hansen, E., Nybakk, E., \& Panwar, R. (2015). Pure versus hybrid competitive strategies in the forest sector: Performance implications. Forest Policy and Economics. https://doi.org/10.1016/j.forpol.2015.02.001

Harrison, J. S. (2003). Strategic analysis for the hospitality industry. Cornell Hotel and Restaurant Administration Quarterly, 44(2), 139-152.

Jaoua, A. (2005). La double-domination: une nouvelle approche d'un avantage concurrentiel. Revue internationale sur le travail et la société, 3(2), 250-271.

Johnson, G., Scholes, K., \& Whittington, R. (2008). Exploring corporate strategy (8th ed.). Prentice Hall, FT, Paris.

Jusoh, R., \& Parnell, J. A. (2008). Competitive strategy and performance measurement in the Malaysian context. Management Decision, 46(1), 5-31. https://doi.org/10.1108/00251740810846716

Khotha, S., \& Vadlamani, B. L. (1995). Assessing generic strategies: An empirical investigation of two competing typologies in discrete manufacturing industries. Strategic Management Journal, 16(1). https://www.jstor.org/stable/2486947

Le Roy, F. (2001). Agressivité concurrentielle, taille d'entreprise et performance. Revue Internationale des PME, 14(2). https://doi.org/10.7202/1008692ar.

Le Roy, F. (2003). Concepts et mesures en stratégie: retour sur le cas de la stratégie concurrentielle. Congrès Histoire et Gestion des Organisations, Université de Toulouse 1, Toulouse.

Le Roy, F. (2004). La concurrence: entre affrontement et connivance. Revue française de gestion, 30(148), $149-152$.

Mia, L., \& Clarke, F. B. (1999). Market competition, management accounting systems and business unit performance. Management Accounting Research, 10, 137-158. https://doi.org/10.1006/mare.1998.0097

Miles, R. E., \& Snow, C. C. (1978). Organizational Strategy, Structure, and Process. New York: McGraw-Hill. 
https://doi.org/10.2307/257544

Miller, D. (1988). Relating Porter's business strategies to environment and structure: Analysis and performance implications. Academy of Management Journal, 31(2). https://doi.org/10.2307/256549

Miller, D. (1992). The Generic Strategy Trap. Journal of Business Strategy, 13(1), 37-41. https://doi.org/10.1108/eb039467

Moses, A., Adjei, M. C., \& Mensa-Bonsu, I. F. (2008). Competitive Strategy, Environmental Characteristics and Performance in African Emerging Economies: Lessons from Firms in Ghana. Journal of African Business, 9(1), 93-120. https://doi.org/10.1080/15228910802052732

Murray, A. (1988). A Contingency View of Porter's "'Generic Strategies". Academy of Management Review, 13(3), 390-400. https://doi.org/10.2307/258087

Nahar, A. A. (2012). Competition and Organizational Performance: Empirical Evidence from Jordanian Firms. Business Management, Tafilah 66110, Jordan, $J$ Economics, 3(1), 13-17. https://doi.org/10.1080/09765239.2012.11884947

Nayyar, P. R., \& Karen, A. B. (1994). Competitive Agility: A Source of Competition Advantage based on Speed and Variety. Advances in Strategic Management, 10(4), 193-222.

Ortega Pertusa, E., Claver-Cortés, E., Molina-Azorín, J., \& Euram, F. (2007). Pure, hybrid or "stuck-in-the-middle" strategies? A revision and analysis of their effects on firm performance. Working Paper, May. http://hdl.handle.net/10045/12663

Ortega, J. R. M. (2010). Competitive strategies and firm performance: Technological capabilities' moderating roles. Journal of Business Research, 63, 1273-1281. https://doi.org/10.1016/j.jbusres.2009.09.007

Parker, B., \& Helms, M. (1992). Generic strategies and firm performance in a declining industry. Management International Review, 32(1), 23-39. https://www.jstor.org/stable/40228086

Parnell, J. A. (2011). Strategic capabilities, competitive strategy, and performance among retailers in Argentina, Peru and the United States. Management Decision, 49(1), 139-155. https://doi.org/10.1108/00251741111094482

Penrose, E. T. (1959). The Theory of the Growth of the Firm. Oxford University Press: Oxford. https://doi.org/10.1093/0198289774.001.0001

Pertusa, O. E. M., Molina-Azorin, J. F., \& Claver-Cortés, E. (2009). Competitive Strategies and Firm Performance: A Comparative Analysis of Pure, Hybrid and âStuck-in-the-middle Strategies in Spanish Firms. British Journal of Management, 508-523. https://doi.org/10.1111/j.1467-8551.2008.00597.x

Peteraf, M. (1993). The cornerstones of competitive advantage: A resource-based view. Strategic Management Journal, 14(3), 179-191. https://doi.org/10.1002/smj.4250140303

Porter, M. (1982). Choix stratégique et concurrence. Economica, Paris.

Porter, M. E. (1980). Competitive Strategy: Techniques for Analyzing Industries and Competitors. New York: Free Press.

Porter, M. E. (1985). Technology and Competitive Advantage. Journal of Business Strategy, 5(3), 60-78.

Smith, K. G., \& Grimm, C. M. (1987). Environmental Variation, Strategic Change and Firm Performance: A Study of Railrod Deregulation. Strategic Management Journal, 8, 363-376. https://doi.org/10.1002/smj.4250080406

Spanos, Y. E., \& Lioukas, S. (2001). An Examination into The Causal Logic of Rent Generation: Contrasting Porter's Competitive Strategy Framework and The Resource-Based Perspective. Strategic Management Journal, 22, 907-934. https://doi.org/10.1002/smj.174

Spanos, Y., Lioukas, S., \& Zaralis, G. (2004). Strategy and Industry Effects on Profitability: Evidence from Greece. Strategic Management Journal, 25(2). https://doi.org/10.1002/smj.369

Tan, J., \& Litschert, R. J. (1994). Environment-strategy relationship and its performance implications: An empirical study of Chinese electronics industry. Strategic Management Journal, 15, 1-20.

Tavitiyaman, Qu, H. L., \& Zhang, H. Q. (2011). The impact of industry force factors on resource competitive strategies and hotel Performance Pimtong International. Journal of Hospitality Management, 30, 648-657. https://doi.org/10.1016/j.ijhm.2010.11.010 
Teece, D., Pisano, G., \& Shuen, A. (1997). Dynamic capabilities and strategic management. Strategic Management Journal, $18(7), \quad 509-533$. https://doi.org//10.1002/(SICI)1097-0266(199708)18:7<509::AID-SMJ882>3.0.CO;2-Z

Ward, P. T., \& Duray, R. (2000). Manufacturing strategy in context: Environment, competitive strategy and $\begin{array}{llll}\text { manufacturing strategy. Journal of Operations Management, } 18, & 123-138 .\end{array}$ https://doi.org/10.1016/s0272-6963(99)00021-2

Weerawardena, J. (2003). The role of marketing capabilities in innovation-based competitive advantage. Journal of Strategic Marketing, 11, 15-35.

Weerawardena, J., O'Cass, A., \& Julian, C. (2006). Does industry matter? Examining the role of industry structure and organizational learning in innovation and brand performance. Journal of Business Research, 59, 37-45. https://doi.org/10.1016/j.jbusres.2005.02.004

Wernerfelt, B. (1984). A Ressource View of the Firm. Strategic Management Journal, 5(2), 171-180. https://doi.org/10.1002/smj.4250050207

Zahra \& Covin. (1993). Business strategy technology policy and firm performance. Strategic Management Journal, 14, 451-478. https://www.jstor.org/stable/2486755

Zgarni, A., \& Gharbi, L. (2019). The Impact of Competition Intensity and Strategic Capabilities on Competitive Strategic Business Choices: The Case of Tunisian Manufacturing Industries. International Review of Management and Marketing, 9(1), 144-151. https://doi.org/10.32479/irmm.6275

\section{APPENDIX: Table A.1: Tests' Results of research hypotheses}

\begin{tabular}{cccc}
\hline \multirow{2}{*}{ Variables' Relationship } & \multicolumn{2}{c}{ Estimated beta } & \multirow{2}{*}{ CR } \\
\cline { 2 - 3 } SC<--IC & NS &, $377^{* * *}$ & \\
\hline SD<--IC &, 382 &, $238^{* * *}$ & 5,788 \\
SCON<--IC &, 238 &, $439^{* * *}$ & 3,476 \\
SHYB<--IC &, 435 &, $296^{* * *}$ & 6,953 \\
SC<--CM &, 405 &, $544 * * *$ & 4,287 \\
SD<--CT &, 715 &, $536^{* * *}$ & 8,122 \\
SD<--CTI &, 584 &, $444 * * *$ & 7,116 \\
SCON<--CMK &, 443 &, 035 & 6,169 \\
SCON<--CMCH &, 045 &, 051 &, 468 \\
SHYB<--CS &, 050 &, $563 * * *$ &, 683 \\
\hline
\end{tabular}

***, $* *, *$ : significative at $1 \%, 5 \%, 10 \%$

IC: Competitive Intensity, CS: Strategic Capabilities, CM: managerial capabilities, CT: technological capabilities, CTI: information technological capabilities, CMK: Marketing capabilities, CMCH: linking Market capabilities. SC: cost dominance, SD: differentiation, SCON: concentration, SHYB: hybrid strategy.

\section{Copyrights}

Copyright for this article is retained by the author(s), with first publication rights granted to the journal.

This is an open-access article distributed under the terms and conditions of the Creative Commons Attribution license (http://creativecommons.org/licenses/by/4.0/). 